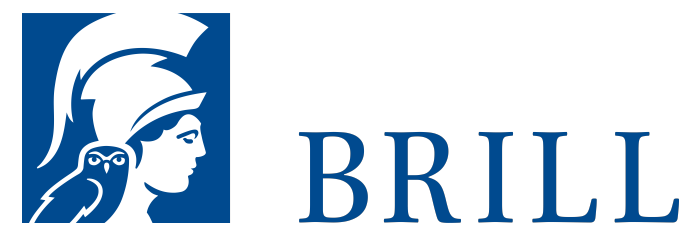

\title{
The Islamic Law of Personal Status
}

Third Revised and Updated Edition

Author: Jamal J. Nasir

This new edition of the authoritative English-language treatment of Islamic personal status law gives practitioners and courts throughout the world direct access to this important body of law in its most up-to-date development. All Middle Eastern and North African Arab states are covered; new to this edition is coverage of recent provisions enacted in Kuwait, Yemen, and Sudan. The chapter on dissolution of marriage has been completely revised to reflect current legal interpretation and judicial practice in this rapidly changing area of Islamic law. Also new and especially valuable are English versions, for the first time anywhere, of fundamental Shiite and Jaafari legal works with the most thorough analysis and commentary available in any non-Arabic source.

Dr. Nasir's much-appreciated methodology has been continued since the very successful first edition of 1986 . For each topic e.g., marriage, dower, dissolution of marriage, parentage, inheritance, and waqf - he begins with a consideration of the subject in Sharia law, and then goes on to present legislation and contemporary views, in particular Arab countries. This approach, while it clearly manifests the continuity of Islamic law respecting personal status, is of great practical value to judges and practitioners, especially those who must resolve disputes under Islamic law in non-Muslim countries.

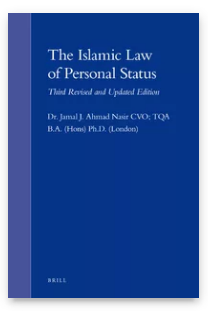

Pages: $x v i, 272$

pp.

Language:

English

Subjects:

Islamic Law,

Middle East and

Islamic Studies,

Comparative

Law,

International

Law

Publisher: Brill

E-Book (PDF)

Released online:

O2 Jun 2020

ISBN: $978-90-$

04-18219-6

List price

USD $\$ 226.00$

Hardback

Publication date:

3o Sep 2009

ISBN: 978-90-

04-17715-4

List price

USD \$226.oo 
For more information see brill.com

Order information: Order online at brill.com +44330 333 0049 | customerservices@brill.com Submission information: brill.com/authors

Titles published by Brill | Fink, Brill | mentis or Brill | Schöningh: +49(o)715413279216| brill@brocom.de 